\title{
PERUBAHAN UKURAN TOKOH WAYANG BIMA DARI ZAMAN KARTASURA SAMPAI ZAMAN SURAKARTA
}

\author{
Yanti, Dendi Pratama \\ Desain Komunikasi Visual \\ Fakultas Bahasa dan Seni, Universitas Indraprasta PGRI \\ Jl. Nangka No. 58 C Tanjung Barat Jagakarsa, Jakarta Selatan \\ agstnyanti@gmail.com
}

\begin{abstract}
Abstrak
Bima adalah salah satu tokoh dalam pewayangan Jawa yang disebut dengan Wayang Purwa dengan adaptasi dari cerita Mahabarata dan Ramayana, Bima juga seorang satria yang memiliki sifat jujur, ulet, tidak mudah putus asa. Dalam pewayangan Bima digambarkan beberapa bentuk yang disebut Wanda, bentuk Wanda tersebut bisa dilihat dari perkembangan zamannya. Penelitian ini bertujuan untuk menjadi bahan referensi bagi peneliti sejenis dan mengetahui wawasan lebih luas mengenai kisah pewayangan salah satunya adalah tokoh Bima. Penelitian ini merupakan penelitian kualitatif dengan proses penelitian riset yang sifatnya deskriptif. Hasil penelitian yaitu menginformasikan pengenalan tokoh Bima dan mengetahui perkembangan zaman Kartasura dan zaman Surakarta dari perbedaan bentuk wayang Bima. Diperoleh melalui sumber beberapa referensi tercetak ataupun elektronik. Diharapkan dengan adanya artikel ini kita dapat lebih mengapresiasikan budaya bangsa terutama kisah pewayangan.
\end{abstract}

Kata Kunci: Perkembangan, Ukuran, Bentuk Bima

\begin{abstract}
Bima is one of the charecter in Javanese puppet called purwa puppet which adapted from Mahabarata and Ramayana stories, Bima is also a warrior who has honest, resilient, not easily desperated. In the puppet, Bima described several forms called wanda, the form of the wanda can be seen form the development of the times. This study aims to be a reference material for similar researchers and to know more broad insights about puppet stories, one of them is Bima. This research is a qualitative research with a descriptive research process. The results of this study is able to inform the introduction of Bima character and find out the development of Kartasura and Surakarta epochs from the differences in the form of Bima puppet. Obtained from the source of several printed or electronic references. By having this article hopefully we can be more appreciate the nation's culture, especially puppet stories.
\end{abstract}

Keywords: Development, Size, Form Bima

\section{PENDAHULUAN}

Wayang kulit merupakan salah satu kebudayaan yang dikagumi oleh masyarakat Indonesia dan Internasional. Kesenian wayang telah diangkat sebagai budaya agung budaya dunia oleh UNESCO tanggal 7 November 2003.

Di daerah Jawa cerita yang popular yang tersebar di masyarakat adalah cerita Ramayana dan Mahabarata, salah satu tokoh dalam cerita tersebut adalah Bima. Bima adalah salah satu tokoh dalam pewayangan Jawa yang disebut wayang purwa. Bima juga seorang satria yang merupakan putra Pandu Dewanata, yang memiliki nama lain seperti Werkudara, Bimasena, Jayalaga, 
Kusumayuda, Kusumadilaga, Wayuninda, Pandusiwi, Kunthisunu, Gandawastratmaja dan Bayu Putra.

Dikalangan penggemar pewayangan, Bima dianggap mewakili karakter-karakter seorang yang jujur, lugas, ulet, tidak pernah putus asa, spontan dan tak pernah menghindari tantangan. Namun, Bima pun dikenal sebagai kesatria yang tegas kepada musuhnya yang jahat (Solichin dkk., 2017:174). Bima ini berperawakan tinggi, besar, gagah, berkumis, dan berjenggot. Pakaiannya juga khas berkain Poleng Bang Bintulu (Solichin dkk., 2017:174).

Bima memiliki beberapa senjata diantaranya Kuku Pancanaka, Gada Rujakpolo dan Lukitasari, dan Bargawastra yang ukurannya besar sekali, anak panah itu dapat digunakan berkalikali karena Bargawastra selalu kembali kepada pemiliknya setelah mengenai sasarannya. sedangkan ilmu kesaktian yang dimiliki oleh Bima adalah Bandung Bandawasa, Ketuk Lindu, dan Blabak Pengantol-antol ajian secepat angin yang berkekuatan delapan ekor Gajah (Solichin dkk., 2017: 194-195).

Dalam dunia pewayangan Bima digambarkan dalam beberapa bentuk atau yang disebut dengan wanda yang berguna sebagai penggambaran ekspresi dalam gaya Surakarta. Beberapa wanda tersebut yaitu wanda Gurnat, wanda Suro, wanda Kartosuro, wanda Sindung, wanda Lindhu Panon, dan wanda Jagur. Wanda-wanda tersebut digunakan untuk menggambarkan ekspresi dalam adegan pertunjukan wayang kulit purwa.

Selain itu dari bentuk wanda dapat dilihat dari perkembangan zaman proses pembuatan boneka wayang. Pada artikel ini membahas perkembangan yang dilihat dari perbedaan bentuk ukuran wanda Bima dari zaman Kartasura sampai zaman Surakarta.

\section{METODE PENELITIAN}

Metode penelitian ini digunakan metode kualitatif yang bersifat deskriptif. Peneliti dengan cara menguraikan, hasil wawancara dengan Bambang Suwarno (Pedalang) catatan data dan rekaman yang dapat dideskripsikan kedalam bentuk kalimat, sehingga dapat menghasilkan kesimpulan dalam bentuk akhir. Kemudian memahami dengan membaca dan menganalisis proses pemahaman yang sesungguhnya.

Pada tahap demi tahap berbagai mengenai objek dicari referensinya, lalu dikaitkan dengan latar belakang mengenai objek sehingga terjadi hubungan bermakna antara berbagai komponen penelitian.

\section{PEMBAHASAN}

Pengenalan Tokoh Bima "Tokoh Wrekudara yaitu, bentuk dari wayang bermata telengan yang artiya mentheleng (bulat), berhidung dempak yang artinya tumpul, berkumis, berjenggot, dan berpupuk di dahi yang dinamakan (Pupuk Mas Rineka), bersanggul bentuk supit udang" (Hardjowirogo, dalam Saptodewo, 2015: 23-24). Bima juga memiliki busana dan perhiasan seperti Sumping Kastuba merupakan hiasan bagian telinga yang berbentuk memanjang seperti tubuh ikan dengan bagian belakang yang mengecil dan membengkok ke atas.

Anting-anting merupakan aksesoris yang dipakai di telinga, bentuk anting-anting seperti bunga melati yang mekar berhiasan ukiran berwarna keemasan. Kemudian Sangsangan merupakan aksesoris berbentuk kalung yang bentuknya setengah lingkaran, seperti bulan sabit. Bima juga memiliki Klat Bahu terletak dilengan kanan ataupun kiri dengan bentuk lingkaran seperti gelang. Klat Bahu tersebut berbentuk seperti kelopak bunga.

Gelang Candrakirana, gelang ini hampir mirip dengan Klat Bahu yaitu dipergelangan tangan. Gelang ini dipakai baik dipergelangan kanan maupun kiri. Kuku Pancanaka, yaitu kuku yang berbentuk taring, dan tangan mengepal. Porong Nagaraja merupakan busana yang berbentuk seperti celana pendek yang berhiaskan kepala naga, terletak paha bagian kanan maupun kiri celana tersebut.

Kemudian Dodot Poleng Bang Bintulu ini adalah busana yang menutupi bagian pinggang sampai dengan kaki dengan motif persegi, dari setiap motif persegi tersebut memiliki masing-masing warna yaitu merah, hitam, kuning, dan putih (Suwarno, 2018). / Gambar 1. 
Bimasena (Sumber: Koleksi Bambang Soewarno, Foto Yanti, 2018) Gambar 2. Hubungan Pernikahan dan Keturunan (Sumber: Saptodewo, F. 2014: 105) / Gambar 3.

Bentuk Wanda Bima (Sumber: Koleksi Bambang Soewarno, Foto Yanti, 2018) Pada gambar diatas menjelaskan ukuran bentuk wayang Bima, huruf (A) ukuran tinggi bentuk wayang Bima, huruf (B) lebar bentuk pada wayang Bima, huruf (C) lebar bahu pada bentuk wayang Bima, huruf (D) lebar pelemahan jarak untuk menyambungkan kaki depan dan kaki belakang, huruf (E) lebar kaki depan dan kaki belakang, huruf (F) tinggi lengan atas depan, huruf (G) tinggi lengan atas belakang, huruf $(\mathrm{H})$ tinggi lengan bawah depan, huruf (I) tinggi lengan bawah belakang, huruf (J) diameter mata pada bentuk wayang Bima. Tabel 1.

Beberapa Ukuran Boneka Wayang Wanda Bima _ _ _ _ _ _ _ A_Tinggi_61,8 cm _62,4 cm _65 cm _65,8 cm _73 cm _75 cm _ _B _Lebar_36 cm $39,6 \mathrm{~cm} \_40,7 \mathrm{~cm} \_38,8 \mathrm{~cm}$ _43 cm _42 cm _ _C_Bahu _25,1 cm_27,4 cm_27,1 cm_25,2 cm_27 cm_27,7 cm _ D _Pelemahan Jarak_13,5 cm _ $15 \mathrm{~cm} \_11,6 \mathrm{~cm} \_14,4 \mathrm{~cm} \_14,8 \mathrm{~cm} \_17 \mathrm{~cm}$ _ _E _Kaki Depan/Belakang _8,3 cm _ $16 \mathrm{~cm} \_9,6 \mathrm{~cm} \_9,5 \mathrm{~cm} \_11 \mathrm{~cm} \_9,1 \mathrm{~cm}{ }_{-}$F _Lengan Atas Depan _16,3 cm _18,6 cm _16,3 cm _ 16,4 cm_19,6 cm _ 18,4 cm _ _G_Lengan Atas Belakang _ 17,9 $\mathrm{cm} \_18,6 \mathrm{~cm} \_17,8 \mathrm{~cm} \_18 \mathrm{~cm} \_20,9 \mathrm{~cm} \_19,3 \mathrm{~cm} \_$_H _Lengan Bawah Depan _13,9 cm _12,7 cm_14,2 cm_14,6 cm_19 cm_15,6 cm __I_Lengan Bawah Belakang _ 15,7 cm_13,8 cm_15,7 $\mathrm{cm} \_15,1 \mathrm{~cm} \_20,7 \mathrm{~cm} \_17,4 \mathrm{~cm} \_$J J Diameter Mata $\_1,3 \mathrm{~cm} \_1,5 \mathrm{~cm} \_1,5 \mathrm{~cm} \_1,3 \mathrm{~cm} \_1,4 \mathrm{~cm}$ _1, $4 \mathrm{~cm}$ _ Sumber: Yanti, 2018 Pada tabel tersebut adalah ukuran-ukuran bentuk wanda Bima koleksi Bambang Suwarno, yang menyimpulkan bahwa wanda memiliki ukuran yang berbeda beda karena, pada zaman kraton Kartosuro (Kartasura) ke Surokarto (Surakarta) zaman PB2 yaitu zaman Kartasura yang sekarang menjadi zaman Surakarta, sebelum pecah menjadi kota Solo.

Wayang Solo pada awalnya itu ukurannya gemuk-gemuk dan pendek-pendek, Setelah menjadi Surakarta wayang bentuk Bima ini ditambahkan 1 (satu) pelemahan, (pelemahan yang artinya untuk menyambungkan kaki depan dan kaki belakang), yang pada akhirnya menjadi lebih tinggi bentuknya, dan wayang Solo itupun bentuk wayangnya memang lebih tinggi (Bambang Suwarno, 2018).

Pada wanda Bima tersebut mempunyai bentuk ukuran yang berbeda-beda, bisa kita lihat dari tabel diatas wanda Gurnat memiliki ukuran paling kecil diantara wanda-wanda lainnya, karena wanda Gurnat masuk dalam perkembangan zaman Kartasura yang bentuk boneka wayangnya masih ukuran kecil. Kemudian wanda Suro wanda yang tingginya tidak jauh berbeda dengan wanda Gurnat. Wanda Suro ini masih tergolong zaman Kartasura.

Begitupun dengan wanda Kartosuro yaitu wanda yang ukuran bentuknya dinaikkan pelemahannya menjadi lebih tinggi dari wanda Gurnat dan Suro. Wanda kartosuro ini pun juga masih dalam tergolong zaman Kartasura. Setelah itu wanda Sindung. Wanda Sindung ini berukuran tingginya tidak terpaut jauh dengan wanda Kartosuro, akan tetapi wanda Sindung ini sudah memasuki dalam perkembangan zaman Surakarta yang dimana bentuk boneka wayangnya sudah dinaikkan pelemahannya, menjadi lebih tinggi dibandingkan dengan boneka wayang zaman Kartasura.

Kemudian wanda Lindhu Panon dan Wanda Jagur yang ukuran bentuknya tidak jauh berbeda, ukurannya tinggi dan masuk tergolong pada zaman Surakarta. Berikut adalah simpulan dari data tabel diatas, dengan adanya tabel tersebut kita bisa membanding-bandingkan dari wanda satu dengan wanda lainnya, dan bisa kita lihat bahwa semua bentuk wanda tidak semua ukuran sama.

Boneka wayang ini bisa kita ekspresikan dengan selera mungguh, (disesuaikan atau pas) dengan karakter dan pelukisannya (Bambang Suwarno, 2018). Pengertian Wanda dalam wayang konon diciptakan oleh Sultan Agung Hanyokrokusumo beliau menciptakan wayang dengan berbagai wanda untuk menegaskan watak dan karakter tokoh yang diberi wanda tersebut. Menurut R.M.

Sulardi wanda adalah gambaran dari watak manusia yang tidak pernah mati, jadi gambaran wayang kulit kira-kira tidak akan mati hingga akhir zaman. (Wardianto, 2011: 29-28). wanda juga dapat diartikan sebagai tampilan bentuk fisik wayang kulit. Wanda berkaitan dengan penggambaran air muka tokoh yang berhubungan dengan keadaan jiwa. 
Bisa juga dikatakan wanda penggambaran suatu hati tokoh wayang tertentu dengan kondisi yang tertentu pula. Misalnya wajah manusia yang sedang marah atau kesal tentunya sangat berbeda dengan wajah yang sedang senang (Wardianto, 2011: 29-30). Wanda Sindung / Gambar 4. Wanda Sindung (Sumber: Koleksi Bambang Soewarno, Foto Yanti, 2018) Wanda Sindung ini belum adanya Gelungan dan masih berambut pendek, berwarna keemasan, dan bentuk kepalanya tidak terlalu menunduk. Wanda Sindung ini pun bentuk ukurannya terlihat tinggi dan ramping. Wanda Suro / Gambar 5.

Wanda Suro (Sumber: Koleksi Bambang Soewarno, Foto Yanti, 2018) Bentuk wanda Suro ini _ kepalanya sangat menunduk berdekatan dengan bahu, pada wanda Suro ini belum memakai celana, hanya ada ornamen yang masih digambarkan dengan tekstur, dan mempunyai postur tubuh terlihat pendek, gemuk, rambut belum tergelung sama halnya dengan wanda Sindung. Wanda Kartosuro / Gambar 6.

Wanda Kartosuro (Sumber: Koleksi Bambang Soewarno, Foto Yanti, 2018) Wanda Kartosuro mempunyai bentuk tubuh berwarna emas terlihat lebih keker (singset) dan rambut sudah bergelung, ukuran lingkaran gelungnya lebar, wanda Kartosuro ini juga belum memakai celana, baru hanya digambarkan dengan teksturnya saja sama dengan wanda Suro. Wanda Gurnat / Gambar 7.

Wanda Gurnat (Sumber: Koleksi Bambang Soewarno, Foto Yanti, 2018) Bentuk wanda Gurnat ini terlihat pendek, dan ramping, kedua bahunya rata dibandingkan dengan wanda-wanda lainnya, namun bahu belakang tetap sedikit lebih tinggi, dan ukuran lingkaran gelungnya lebar. Wanda Lindhu Panon / Gambar 8. Wanda Lindhu Panon (Sumber: Koleksi Bambang Soewarno, Foto Yanti, 2018) Wanda Lindhu Panon ini bertubuh gemuk dan tinggi, bahu belakang lebih tinggi dari pada bahu depan, wajahnya sangat menunduk sekali, seolah-olah memandang kebawah, tekstur bentuk boneka wayangnya kasar, dan lingkaran gelungnya lebar.

Wanda Jagur / Gambar 9. Wanda Jagur (Sumber: Koleksi Bambang Soewarno, Foto Yanti, 2018) Wanda Jagur ini hampir sama dengan wanda Lindhu Panon, akan tetapi tundukannya yang berbeda, ukuran bentuknya paling tinggi diantara bentuk wanda-wanda Bima lainnya, dan wanda Jagur ini memiliki seluruh tubuh berwarna hitam, warna hitam terlihat lebih gagah dan langsing (Bambang Suwarno, 2018).

\section{SIMPULAN}

Berdasarkan hasil penelitian tersebut, maka beberapa hal yang dapat penulis simpulkan adalah ukuran bentuk wayang Bima tidak jauh berbeda, karna sebenarnya boneka wayang memang kecil dan sesuai pada ukuran biasanya, menyesuaikan atau mungguh (pas). Pada zaman Kartasura ke Surakarta zaman (PB2), sebelum pecah menjadi solo wayang nya memang gemukgemuk dan pendek-pendek, setelah menjadi Surakarta wayang ini ditambah satu pelemahan yang akhirnya menjadi lebih tinggi.

Dengan adanya artikel ini semoga dapat bermanfaat untuk peneliti sejenisnya, dan menambah wawasan mengenai perubahan ukuran tokoh Bima dari zaman Kartasura sampai zaman Surakarta.

\section{DAFTAR PUSTAKA}

Saptodewo, F. (2016). Perancangan bentuk tokoh wayang tetuka Saat balita. Jurnal Desain, 3(01), 21-26.

Saptodewo, F. (2019). Perancangan Visualisasi Tokoh Wayang Bambang Tetuka. Jurnal Desain, 1(02), 102-109.

Solichin, Suyanto, Sumari. (2017). Ensklopedi Wayang Indonesia. Jakarta: Sena Wangi. 
Wardianto, F. (2011). Makna Busana Raden Werkudara Wanda Mimis Wayang Kulit Purwa Gagrak Surakarta. Skripsi. Tekstil Fakultas Sastra dan Seni Rupa, Universitas Sebelas Maret, Surakarta. Diambil dari https://digilib.uns.ac.id/dokumen/download/22343 /NDUOMzk=/Makna-Busana-RadenWerkudara-Wanda-Mimis-Wayang-Kulit-PurwaGagrak-Surakarta-abstrak.pdf 